\title{
On the Divergence of Voiced Lateral Approximants in Indo-European languages
}

\author{
Georgiy M. Telezhko ${ }^{\bowtie}$ \\ Sole Proprietorship, St Perersburg, Russia \\ 凶urate@bk.ru
}

Introduction. This article is based on the results of a comparison of a number of SerboCroatian/Slovenian lexemes with a palatal lateral approximant $[\Lambda]$ and Western Slavic lexemes with a velarized lateral approximant [t] with related lexemes in Slavic and other Indo-European (IE) languages. It is shown that the Balkan-Slavic $[\Lambda]$ irregularly corresponds to the phonemes [I'] and [j] of other Slavic languages and even some IE languages beyond the Slavic group. It is also shown that the West Slavic [t] irregularly corresponds to the phonemes $[\mathrm{I}]$ and $[\mathrm{W}] /[\mathrm{V}]$ of other Slavic and IE languages. Because of this irregularity, these phonetic correspondences are difficult to explain with local dialect features.

Methodology and sources. A model based on the generalization of instrumental studies that showed that palatal sounds are characterized by instability of articulation is proposed. This leads to their divergent evolution, transformation into sounds with different stable zones of articulation.

In the proposed model, the Proto-Indo-European (PIE) voiced lateral approximants * [t] and * $[\Lambda]$, forming the opposition "hard consonant - soft consonant", in the process of phonetic evolution in IE languages were split into variants with a clearer articulation: velarized $*[t]>$ solid alveolar lateral [l] and bilabial fricative [W]; palatal $*[\Lambda]>$ soft alveolar lateral $\left[I^{\prime}\right]$ and palatal approximant [j]. Besides, the original consonants have survived in a number of languages.

Results and discussion. Examples of correspondences are given to suggest the presence of $*[t]$ and $*[\Lambda]$ in PIE and Common Slavic prototypes. The newly discovered etymological links, such as the links between Russian lexemes баня 'bath' and балий, бальник 'healer, sorcerer' are being discussed.

Conclusion. With the help of the mechanism of divergent evolution of the palatal lateral approximant ${ }^{*}[\Lambda]$ and the velarized lateral approximant ${ }^{*}[t]$ the irregularity of phonetic correspondences of voiced lateral approximants in Slavic languages can be uniformly explained.

Besides, the acceptance of $*[\Lambda]$ and *[t] in PIE phonology also lets us to establish some previously undetected etymological relations.

Keywords: palatal, velarized, lateral, approximant, phonetic divergence, articulation, Common Slavic language, Proto-Indo-European language.

For citation: Telezhko G. M. On the Divergence of Voiced Lateral Approximants in Indo-European languages. DISCOURSE. 2020, vol. 6, no. 3, pp. 128-136. DOI: 10.32603/2412-8562-2020-6-3-131-139

Conflict of interest. No conflicts of interest related to this publication were reported.

Received 09.04.2020; adopted after review 13.05.2020; published online 25.06.2020

(c) Telezhko G. M., 2020

Контент доступен по лицензии Creative Commons Attribution 4.0 License. This work is licensed under a Creative Commons Attribution 4.0 License.

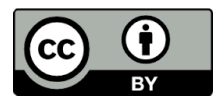




\title{
О дивергенции звонких боковых аппроксимантов в индоевропейских языках
}

\author{
Г. М. Тележко \\ Индивидуальный предприниматель, Санкт-Петербург, Россия

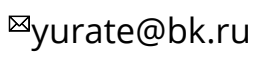

\begin{abstract}
Введение. Данная статья построена на основе результатов сравнения ряда сербохорватских/словенских лексем с палатальным боковым аппроксимантом [ᄉ] и западнославянских лексем с веляризованным боковым аппроксимантом [†] с родственными лексемами в славянских и других индоевропейских (ИЕ) языках. Показано, что балканославянский [ᄉ] нерегулярно соответствует фонемам [l'] и [j] других славянских языков и даже некоторых ИЕ языков за пределами славянской группы. Показано также, что западнославянский [ł] нерегулярно соответствует фонемам [l] и [w]/[v] других славянских и ИЕ языков. Из-за этой нерегулярности эти фонетические соответствия трудно объяснить местными диалектными особенностями.
\end{abstract}

Методология и источники. Предлагается модель, основанная на обобщении инструментальных исследований, показавших, что палатальные звуки характеризуются нестабильностью артикуляции. Это ведет к их дивергентной эволюции, превращению в звуки с различными устойчивыми зонами артикуляции.

В предложенной модели праиндоевропейские (ПИЕ) звонкие боковые аппроксиманты *[t] и *[ᄉ], образующие оппозицию «твердый согласный - мягкий согласный», в процессе фонетической эволюции в ИЕ языках расщеплялись на варианты с более четкой артикуляцией: веляризованный *[†] > твердый альвеолярный боковой [I] и билабиальный фрикатив [w]; палатальный *[ᄉ] > мягкий альвеолярный боковой [l'] и палатальный аппроксимант [j]. Помимо этого в ряде языков сохранились и оригинальные согласные.

Результаты и обсуждение. Приведены примеры соответствий, позволяющие предполагать наличие *[t] и *[ᄉ] в ПИЕ и общеславянских прототипах. Обсуждаются впервые обнаруженные этимологические связи, например, связи между русскими лексемами баня и балий, бальник 'целитель, колдун'.

Заключение. Нерегулярность фонетических соответствий звонких боковых аппроксимантов в славянских языках может быть единообразно объяснена с помощью механизма дивергентной эволюции палатального бокового аппроксиманта *[ᄉ] и веляризованного бокового аппроксиманта *[t].

Кроме того, допущение *[ᄉ] и *[t] в ПИЕ фонологии позволяет установить ранее не обнаруженные этимологические связи.

Ключевые слова: палатальный, веляризованный, боковой, аппроксимант, фонетическая дивергенция, артикуляция, общеславянский язык, праиндоевропейский язык.

Аля цитирования: Тележко Г. М. О дивергенции звонких боковых аппроксимантов в индоевропейских языках // ДИСКУРС. 2020. Т. 6, № 3. С. 128-136. DOI: 10.32603/2412-8562-2020-6-3-131-139

Конфликт интересов. О конфликте интересов, связанном с данной публикацией, не сообщалось.

Поступила 09.04.2020; принята после рецензирования 13.05.2020; опубликована онлайн 25.06.2020

Introduction. In the Balkan-Slavic languages phonology, besides the "soft" alveolar lateral approximant [1'], there is a voiced palatal sound $[\Lambda]$, the articulation of which differs from that of [1']. The palatal lateral approximant $[K]$ is displayed in these languages as following:

- by the letter $s$ (the ligature of $л$ и $b$ ) in Serbian and Macedonian; 
- by the digraph $l j$ in Croatian.

Similarly, in the West-Slavic languages phonology, besides the "hard" alveolar lateral approximant [1], there is a voiced velarized sound [1], the articulation of which differs from that of [1]. This sound opposes to [ $K]$ by the attribute of hardness, as well as [1] opposes [1']. The sound [ $\mathrm{l}$ ] is displayed by the letter $t$ in words of Polish, Kashubian, Slovenian and Lusatian languages before consonants and non-front vowels. In Old Polish this sound was pronounced without contact of the tongue with the alveoli and with a slight lip rounding.

However, the explanation of articulation differences by regional dialect features is not entirely satisfactory, since the correspondence "South Slavic $[\Lambda] \sim$ Slavic [1']", as well as the correspondence "West Slavic [1] Slavic [1]", is not regular. This irregularity, obviously, does not depend on any combinatory or positional conditions, what could be observed comparing Serbian гљива 'mushroom' < Proto-Slavic *gliva and глиб 'mud' < Proto-Slavic *glibъ, as well as in the following examples:

- an Old Serbian toponym Cкònљe [skopKe] in Macedonian is pronounced with [j] - Cкonje [skop'je], and pronounced with [1'] in Russian - Скопле [skopl'e];

- but the Slavic words for 'spear' with the same environment of $[K]$ in Serbo-Croatian kònse [kop $\Lambda \mathrm{e}]$ have the transcriptions: in Slovenian - like in Macedonian above, with [j] - kopje [kop'je], but in Russian - not with [1'] as above, but also with [j] - кonbe [kop'jo], similar with Old Slavic копиє [kopije] (see «копье» in [1]);

- the words for 'boyar' with $[K]$ in intervocalic position in Serbo-Croatian бòљарин [boKarin] have different correspondences with palatal $[K]$ in Old Slavic and Old Russian, cf. Old Slavic больхринъ [bol'ęrinъ] with Russian боярин [bojarin] (see «боярин» in [1]);

- but the words for 'sparrow' with $[\Lambda]$ in the end of Slovenian dialectal vrábelj [wrabe $K$ ] [2, p. 154, 157], in Russian Church Slavic and in Russian have coinciding correspondences: with [j], cf. Church Slavic врабии [vrabij] with Russian воробей [vərebej] (see «воробей» in [1]);

- Polish word dót 'dale' with [1] in the final position corresponds to Upper Lusatian dót and Slovenian dôt also with [1] in the final position, while there is Czech dơl with [1] in the final position (see «дол» in [1]);

- Polish word kót 'pike' also with [1] in the final position and in the same environment also corresponds with High Lusatian kól with [1] in the final position and Czech kill with [1] in the final position, but Slovenian kòl has [1] in the final position, see «кол» in [1];

- similarly, cf. Ukrainian вовк, Old Russian вълкъ, Old Slavic влькъ, Slovenian vôtk, Czech $v l k$ with Ukrainian толк, Old Russian тьлкъ, Old Slavic тлькъ, and with Ukrainian полк, Old Russian пълкъ, Old Slavic плъкъ, Czech pluk 'heap', Polish putk 'regiment' (see «волк», «толк», «полк» in [1]), where the irregular correspondence of Ukrainian [w]/[1] Old Russian, Old Slavic and Czech [1] Polish and Slovenian [1] is observed.

The aim of this article is an attempt to justify divergent mechanisms $*[K]>\left\{[K],\left[1^{\prime}\right],[j]\right\}$ and $*[1]>\{[1],[1],[\mathrm{w}]\}$, which could explain given irregularities.

Methodology and sources. The palatal $[K]$ is not only specific for Balkan-Slavic languages but also for a number of Roman and some other languages (for example, in Spanish, French and Italian it is denoted by $l l$, ill and gli combinations of letters). Roman $[\Lambda]$ in Slavic languages is usually transcribed as [j], for example, a Spanish toponym Mallorca [maKorka] is transcribed as [majorka] (Russian Майорка). The transcription [mal'jorka] (Russian spelling: Мальорка) is, 
probably, influenced by the transliteration of the word, as well as Russian бульон is influenced by transliteration of French bouillon [bujo], however, ill in bouillon points to the lateral approximant $*[K]$ in the ancestor of French bouillon which had evolved into [j]. An Italian example of preservation of $*[K]$ is tagliare [ta $\Lambda^{\prime} K$ are] 'to cut', cf. with Latin taliō 'I cut', Romanian tăia 'to cut', which comparison promptly shows all the three above mentioned possibilities of evolving of *[K].

We will try to show a possible reason for different pronunciation of the palatal $[K]$ in Slavic languages.

Instrumental measurements performed by $D$. Recasens have shown that the palatal $[K]$ in languages where it exists is characterized with uncertain, unstable articulation, and may be described differently in different cases: as palato-alveolar, postalveolar or postalveolar-prepalatal $[3$, p. 22]. Being unstable the articulation place of the palatal consonant $[\Lambda]$ tends to move to one of more stable positions: either closer to the alveoli (i. e. forward), evolving to [1'], or backward to the soft palate, with creation of [j].

We have the right to assume that if the sound $[K]$ was used on the Common Slavic phase of Slavic languages evolution, then, due to its instability, the range of its articulation variants during the phonetic evolution process was supposed to include the extreme variants [j] and [1'] which we observed in the examples with the name of Serbian town Скопье / Скопле, the French borrowing бульон [bul'jon] from bouillon [bujo], the name of Spanish island Майорка / Мальорка and in related Italian tagliare, Latin taliō 'cut', Romanian tăia.

The above assumption permits us to trace the signs of palatal $*[K]$ presence in words of the Proto-Slavic language phase, namely:

- the presence of $[\Lambda]$ which is denoted with the letter $s$ in Serbian or Macedonian analogs (or with digraph $l j$ in Croatian or Slovenian analog), while there is [j] or, possibly, [1'] in the same position in etymologically related words;

- fluctuation [1'] [j] (or [i]) in etymologically related words.

In Russian, Old Slavic and Serbo-Croatian words with the meaning 'boyar' (see above) we can see both of these signs of palatal *[K]'s presence in the ancestor word [4].

Common Slavic $*[K]$ split resulted mainly in [1'] in words of East-Slavic languages in the position between a word stem ending with a labial consonant and an ending. This sound is considered as the result of an epenthesis, for example, in Russian земля (sеe «земля» [1]), and not as a suffix or a part of it, but here it does not matter as the epenthesis / suffix may have appeared as $*[K]$ on the Common Slavic phase.

Uncertain double articulation of velarized lateral approximant $*[1]$, just as in the case of wide range of palatal lateral approximant pronunciation, also tended to the articulation place displacement to one of the two more stable positions. As previously, we have the right to assume that if the sound *[1] was used on Common Slavic phase of Slavic languages evolution, the trend of its articulation to certainty was supposed to spawn new variants, namely, [1] (with purely alveolar articulation) and [w] (with bilabial articulation).

The signs of approximant *[1] presence in words of the Common Slavic language phase (possibly, also in words of the earlier phases) can be formulated the following way:

- the presence of letter $t$ in a West-Slavic (Slovenian, Polish and Lusatian) word, for example as in Slovenian vôtk (see «волк» in [1]), Polish pułk 'regiment', while there is [1] or, possibly, $[\mathrm{w}]$ in the same position in etymologically related words; 
- the alternation $[1] \sim[\mathrm{w}] /[\mathrm{v}]$ in etymologically related words, for example as in Ukrainian вовк, Old Russian вълкъ.

Results and discussion. Here are several examples of groups of Slavic words signifying presence of $*[\Lambda]$ in Common Slavic prototypes:

- 'ground': Russian, Ukrainian, Belorussian земля́, Old Russian, Old Slavic землья, SerboCroatian зѐмљьa, Slovenian zémlja, Polish ziemia, High Lusatian, Low Lusatian zemja (see «земля» [1], the both signs are detected);

- 'drop': Old Slavic капльћ, капињи, Ukrainian ка́пля, Serbo-Croatian кайльа, Slovenian káplja, Polish kapla, kapia (see «капля» [1], the both signs are detected, the split of *[К] is particularly noticeable in Old Slavic and Polish analogs);

- 'spear': Russian копье, Old Slavic копиє, Serbo-Croatian ко̀nље, Slovenian kорje, слвц. kоріja, польск. kорja, Low Lusatian kopje (see «копье» [1]);

- 'ant': Russian муравей, Ukrainian муравель, Russian Church Slavic мравии, Slovenian mrávlja ([mrawאa]), High Lusatian mrowja (see «муравей» [1], here are the both signs);

- 'sparrow': Russian воробей, Ukrainian dialectal горобель, Russian Church Slavic врабии, Slovenian vrábelj ([wrabe $K]$ ) (see «воробей» [1], the both signs are detected);

- 'obey', 'watch': Russian блюсти, наблюдать, Belorussian блюсиь, Old Slavic блюдж, блюсти «хранить, соблюдать», Old Serbo-Croatian бљудем, бљусти (see «блюду» [1], there is no [j] in Slavic analogs, but cf. with related Gothic anabiudan 'to order' with [i] in the position of Slavic [1'] and $[K])$.

Assuming debatably that $*[K]$ used to be a part of source stems of Russian verbs баяmb 'to tell, to witch' and maяmb 'to thaw, to melt' as a formant, we could have got the following interesting synchronic etymological relations:

a) the divergence of the stem *[baK-] $>\{[$ bal'- $]>[$ bal- $]$; [baj- $]\}$ examples:

- *[bal'-], [bal-] > Russian dialectal балить [balit'] 'to chat, to joke' (related to баять [1, see «балить»], pay attention also to North Frisian bālen 'to speak' - commentary of Trubachev, referring to Holthausen, to the article «баю» [1]);

- further on, Russian балий 'healer' (cf. Old Slavic баловати 'to care, to cure', бальник 'healer, sorcerer - the evolution of meanings from 'to tell; to conjure' to 'to cure' is similar to drift from врати 'to tell' to врач 'healer', see «балий» [1]);

- *[baj-] > баяmь [bajat'], бaumb [bajit'] 'to tell; to witch, to cure (Russian Church Slavic)' (see «баю» $[1])$;

- interestingly, here is also related *[baKna] > North Russian dialectal байня / байна 'bathhouse', see «банить» [5], further on to Russian баня 'bathhouse' with assimilation of the palatal $[\Lambda]$ and $[n]$ (the semantics is: people used to be healed in bathhouses; morphologically: баю : байня = мылю : мыльня =мелю : мельня = стреляю : стрельня $/$ стрельна $=$ бью : бойня);

b) the divergence of the stem $*[\operatorname{ta} \kappa-]>\left\{\left[\right.\right.$ tal'$\left.^{-}\right]>[$tal- $]$; [taj- $\left.]\right\}$examples:

- [tal'-], [tal-] > Russian тальй 'melted', тал, тальник 'willow(s)'; contrary to Vasmer (see «тал» [1]), the last two words are native Russian, since willows are common in the area of Slavs settlements - the semantics is as follows: willows bloom before the snow melts; Permian dialectal тальмень 'taimen' (see «таймень» [1]) can also be explained via snow melting: taimens prefer cold water, so they tend to move to waters of thawed swamps; 
- *[taj-] > Russian таять 'to melt', Ukrainian, Old Russian таяти; таймень (Siberian taimen, Latin Hucho Taimen, see the semantics for тальмень above);

- here is also, possibly, *[taKna] > тайнa 'mystery', in case if the semantics of stealth (see «тайна» [1]) evolved later and maumь 'to conceal' was originally 'to make melt $\sim$ to make disappear'; morphologically, таять / таить : тайна : тальник = баять / баить : байна: бальник'.

The stem *[ba $\left.\kappa_{-}\right]$is etymologically connected at least with one lexeme outside Slavic, namely, North Frisian word bālen, however, баня is considered to be connected also with Latin balneum 'bathhouse, bath, bathing' (usually as the source for borrowing) and Ancient Greek $\beta \alpha \lambda \alpha v \varepsilon i ̃ o v$ 'bathhouse, bath, bathing'. Here is also Italian bagno [bajno] 'bath; bathhouse' (see «баня» [1]) with assimilation of palatal ancestors [ $K]$ and [n], just like in баня [4].

The stem *[taK-] has also cognates outside Slavic language group, which are related to maяmь:

- with Arian: Ossetian maйbıн 'to melt', Ancient Indian tóyam 'water' (see «таю» in [1]);

- with German: Old English talwgh - the source of tallow 'solid animal fat', Middle Low German talg, Middle Dutch talch - the same, i. e, «melted» - referring to Harper, they do not have any etymology outside German (Search: tallow in [6]); however, Middle Irish delt 'dew' and Old Armenian untin [tel] 'heavy rain' are also considered as related to tallow (<look up $>$ tallow in [7]).

At first sight, the meaning of English tallow and German related lexemes is far from the meaning 'to melt', but the semantic relation of the meaning 'fat' and the meanings 'dew', 'moisture', 'to pour', 'to melt' can be confirmed by the semantic parallel in Russian: лumь 'to let liquid move from a vessel, to produce a liquid stream, a flow' (see «лить» [1]) and related лой 'fat' (see «лой» [1]), and also by the combination of meanings of волога 'fatty liquid' 'moisture' (see «волога» [1]).

So the assumption of the Common Slavic $*[K]$ and the divergence of its articulation caused by the instability of its articulation place not only logically explains the irregular correspondence of Balkan-Slavic $[K]$ to phonemes [1'] and [j] of other Slavic languages but is also useful revealing etymological relations which have not been noticed up to now, such as баня, байня 'bathhouse' бальник 'healer' балить, баять 'to tell, to witch'.

External relations of блюсти and the morphemes * [baא-], *[ta $\left.\kappa_{-}\right]$with the alternation [1] [j] in related lexemes of non-Slavic languages permits us consider the process $*[K]>\{[j] ;[K]$; $\left.\left[1^{\prime}\right]\right\}$ as not exclusively Common Slavic.

Reconstruction of Common Slavic prototypes which contain * $[\Lambda]$ is beyond the scope of this article. As an example, we could mention Proto-Slavic *gliva (the now suggested prototype for Serbian гљива 'mushroom', (<look up> гљива [7]) which is likely to take the form *[g/iva]. Besides, although the consideration of particular verb forms ending with -лю, -лять (for example любить > люблю, влюблять) is relevant to the topic of this article, it should be done in a context wider than defined by the given topic.

The split $*[1]>\{[1],[1],[\mathrm{w}]\}$ is also seen beyond Slavic languages. Here beneath are examples of words whose prototypes may contain the lateral approximant $*[1]$.

Lexemes related to Russian лyz 'meadow':

- with *[1]: Polish łag, łeg 'swamp, forest in the swamp, marshy meadow', Upper Lusatian tuh, Lower Lusatian tug 'grassy swamp' (see «луг» [1]); 
- with *[1] > [1]: Old Slavic лжгъ, Russian, Ukrainian луг, Serbo-Croatian луг 'lowland forest, cane, reeds', Bulgarian $л ъ г(\mathrm{~b} m)$ 'flat, low place under a small forest, grove, shrub, meadow', Slovenian $\log$ 'forest in a low place'; Danish lung 'swampy soil', Swedish toponym Lungen is probably a borrowing from Slavic (see «луг» [1]);

- with *[1] > [w] / [v]: Old Prussian wangus 'meadow', Old Lithuanian vanga - the same, Gothic waggs 'Heaven', Old Saxon wang 'field', Old Icelandic vangr 'field, meadow', the connection of which with луг used to remain unclear (see «луг» [1]);

- with elision of *[1]: Old Norwegian, Danish eng 'meadow', Swedish äng 'meadow' (despite the meanings mismatch, sometimes these words are considered as going back to German words with the meaning 'narrow' (<look up> eng [7]).

Lexemes related to Russian солодкий 'sweet':

- with *[1]: Polish słodki, High Lusatian słódki, Low Lusatian słodki (see «солодкий» [1]);

- with *[1] > [1]: Russian, Ukrainian солодкий, Belorussian соло́дкі, Old Slavic сладъкъ, Bulgarian сла́дък, Serbo-Croatian слӓдак, слаїкка, слаїко, Slovenian sládək, sládka, Czech, Slovak sladký (see «солодкий» [1]);

- with *[1] > [w] / [v]: Sanskrit svadus 'sweet', Latin suavis 'pleasant', suadere 'persuade', Old English swete 'pleasant', Old Saxon swoti, Old Frisian swet, Old High German swuozi (Search: sweet [6]);

- with elision of *[1]: Ancient Greek $\dot{\eta} \delta \dot{s} \varsigma$ 'sweet, delicious', Swedish söt, Danish sød, Middle Dutch soete, Dutch zoet, German süß (Search: sweet [6]).

Lexemes related to Russian солние 'sun':

- with *[1]: Polish słońce, Upper Lusatian słónco, Lower Lusatian styńco (see «солнце» [1]);

- with *[1] > [1]: Old Russian сълньие, Old Slavic сльньие, Bulgarian слъние, Slovenian solnce, Czech slunce, Slovak slnce; Lithuanian sáule, Latvian saũle, Old Prussian saule, Gothic

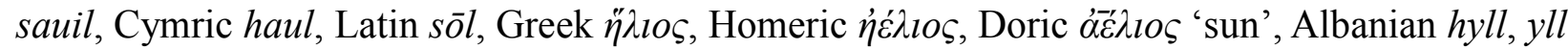
'star' (see «солнце» [1]), Albanian probably influenced by Turkic: Turkish yıldız, Uzbek yulduz (dialectal йүллүз) 'star';

- with *[1] $>[\mathrm{w}] /[\mathrm{v}]$ : Tocharian A swāñce, Tocharian B swāñco, swāñcai- 'ray (of light, sunshine)', Hittite siwatt- 'day' (?) [8, Meaning 'sun'], Ancient Indian svar-Vedic Sanskrit súvar 'sun, light, sky', Avestan hvara, gen. $\chi$ vayg 'sun, sunlight' (see «солнце» [1]), with alternation $[\mathrm{r}] \sim[\mathrm{n}]$ in the end of the stem;

- with elision (or assimilation) of [1]: Ukrainian сонце, Serbo-Croatian сунмце, Ancient Indian súrras, súrryas, Ossetian xyp, Gorhic sunnô, Old High German sunna 'sun' (see «солнце» $[1]$ ), with the alternation $[\mathrm{r}] \sim[\mathrm{n}]$ in the end of the stem.

Lexemes related to Russian maяms 'to thaw, to melt', English tallow 'fat':

- with *[1]: Old Armenian untin [tel] 'heavy rain';

- with *[1] > [1]: Russian mальй 'melted' (remember Russian тальник 'willows' with $*[\Lambda]>[1 '])$, Middle English talwgh 'fat', Middle Irish delt 'dew' (<look up>tallow [7]);

- with *[1] $>[\mathrm{w}] /[\mathrm{v}]$ : English thaw 'to melt', Old English pawian 'to melt something' Old High German douwen, dewen 'to melt' (Search: thaw [6]);

- with elision of *[1]: Sanskrit toyam "to melt" (Search: thaw [6]), Ancient Greek $\tau \dot{\eta} \kappa \omega$ "to melt something". 
Ancient Indian verb toyam 'to melt' in the last example, more likely, should be considered as the result of alternation $*[1] \sim *[K]$ (just like *[1] * *[1'] in лой лить, тал $\sim$ тальник) and the divergence of the palatal partner of $*[1]: *[K]>\left\{\left[1^{\prime}\right],[j]\right\}$.

Conclusion. The given examples show that products of divergence $*[K]>\left\{[\Lambda],\left[1^{\prime}\right],[j]\right\}$ and $*[1]>\{[1],[1],[\mathrm{w}] /[\mathrm{v}],[0]\}$ exist not only in Slavic languages but also in the languages of all groups of the Indo-European family, what lets us to talk about the existence of the both lateral approximants in the PIE phase of the language evolution. For this reason, we may rewrite some PIE prototypes using $[K]$, e. g., Proto-Slavic * gliva (the now suggested prototype for Serbian гљива 'mushroom') could take the form * [gKiva].

Due to the instability of articulation of these sounds, their evolution having led to irregular correspondences:

$-{ }^{*}[K]>[\mathrm{j}]-$ more frequent in East and West Slavic, in Indo-Iranian;

$-*[\Lambda]>\left[l^{\prime}\right]-$ frequent in East and West Slavic;

- *[1]> [1] - more frequent in East and South Slavic;

$-*[1]>[\mathrm{w}]-$ frequent in Old Baltic, Indo-Iranian, Tocharian and German;

$-*[1]>[0]-$ most frequent in Scandinavian.

The acceptance of $*[K]$ and $*[1]$ in PIE phonology also lets us to establish some previously undetected etymological relations.

\section{REFERENCES}

1. Vasmer, M. (1986-1987), Russisches etymologisches Wörterbuch, in Larin, B.A. (ed.), Transl. by Trubachev, O.N., in 4 vol., 2nd ed., Progress, Moscow, RUS.

2. Greenberg, M.L. (2000), A Historical Phonology of the Slovene Language, Universitätsverlag, C. Winter, Heidelberg, GER.

3. Recasens, D. (2013), "On the Articulatory Classification of (Alveolo)Palatal Consonants", Journal of the International Phonetic Association, vol. 43, no. 1, pp. 1-22.

4. Telezhko, G.M. (2016), "ON THE DIVERGENCE OF PALATAL LATERAL APPROXIMANT IN SLAVIC LANGUAGES", Universum: Filologija $i$ iskusstvovedenije [Universum: Philology and Art History], no. 12 (34), available at: http://7universum.com/ru/philology/archive/item/4029 (accessed 26.03.2020).

5. Dal, V.I. (1863-1866), Tolkovyi slovar' [Dahl's explanatory dictionary], available at: http://dic.academic.ru/contents.nsf/enc2p (accessed 28.03.2020).

6. Harper, D.A., Online Etymology Dictionary, available at: http://www.etymonline.com/index.php (accessed 29.03.2020).

7. Wiktionary, available at: https://en.wiktionary.org/wiki/Wiktionary:Main_Page (accessed 28.03.2020).

8. Starostin, S.A., Indo-European etymology, available at: http://starling.rinet.ru/cgi-bin/query.cgi? basename $=\backslash$ datalielpiet\&root=config\&morpho=0_(accessed 29.03.2020).

\section{Information about the author.}

Georgiy M. Telezhko - Can. Sci. (Engineering) (1997), Director of IP "Georgiy Mikhailovich Telezhko", 167-8 Fontanka riv. emb., St Petersburg 190121, Russia. The author of 48 scientific publications. Areas of expertise: comparative linguistics, atmospheric physics, relativity theory. Email: yurate@bk.ru

\section{СПИСОК ЛИТЕРАТУРЫ}

1. Фасмер М. Этимологический словарь русского языка: в 4 т. / пер. с нем. О. Н. Трубачева; под ред. Б. А. Ларина. 2-е изд. стер. М.: Прогресс, 1986-1987. 
2. Greenberg M. L. A Historical Phonology of the Slovene Language. Heidelberg: Universitätsverlag, C. Winter, 2000.

3. Recasens D. On the Articulatory Classification of (Alveolo)Palatal Consonants // J. of the International Phonetic Association. 2013. Vol. 43, № 1. P. 1-22.

4. Тележко Г. М. О дивергенции палатального бокового аппроксиманта в славянских языках // Universum: Филология и искусствоведение: электрон. науч. журн. 2016. № 12 (34). URL: http://7universum.com/ru/philology/archive/item/4029 (дата обращения: 26.03.2020).

5. Даль В. И. Толковый словарь. 1863-1866. URL: http://dic.academic.ru/contents.nsf/enc2p (дата обращения: 28.03.2020).

6. Harper D. Online Etymology Dictionary. URL: http://www.etymonline.com/index.php (дата обращения: 29.03.2020).

7. Wiktionary. URL: https://en.wiktionary.org/wiki/Wiktionary:Main_Page (дата обращения: 28.03.2020).

8. Starostin S. A. Indo-European etymology. URL: http://starling.rinet.ru/cgi-bin/query.cgi?basename= Idatalielpiet\&root=config\&morpho=0_(дата обращения: 29.03.2020).

\section{Информация об авторе.}

Тележко Георгий Михайлович - кандидат технических наук (1997), ИП «Георгий Михайлович Тележко», наб. р. Фонтанки, д. 167, кв. 8, Санкт-Петербург, 190121, Россия. Автор 48 научных публикаций. Сфера научных интересов: сравнительное языкознание, физика атмосферы, теория относительности. E-mail: yurate@bk.ru 